\title{
Host traits, ownership behavior and risk factors of SARS-CoV-2 infection in domestic pets in Mexico
}

\author{
Fabiola Carolina Espinosa-Gómez ${ }^{1}$, Elizabeth Bautista ${ }^{1}$, Oscar Palacios-Cruz ${ }^{1}$, Alejandra \\ Téllez-Ramírez ${ }^{1}$, Daniela Belem Vázquez-Briones ${ }^{1}$, César Flores de los Ángeles ${ }^{1}$, Héctor \\ Aguirre-Alarcón ${ }^{1}$, Carlos Antonio Abella-Medrano ${ }^{1}$, Jorge Luis Escobedo-Straffón ${ }^{1}$, Mario \\ Solís-Hernández ${ }^{2}$, Roberto Navarro-López ${ }^{2}$, and Alonso Aguirre ${ }^{3}$ \\ ${ }^{1}$ Universidad Popular Autonoma del Estado de Puebla \\ ${ }^{2}$ Servicio Nacional de Sanidad Inocuidad y Calidad Agroalimentaria \\ ${ }^{3}$ George Mason University College of Science
}

February 15, 2022

\begin{abstract}
SARS-CoV-2 can infect pets under natural conditions, which raises questions about the risk factors related with susceptibility of these animals to infection. The status of pet infection by SARS-CoV-2 in Mexico it is not well understood. We aimed to estimate the frequency of positive household cats and dogs to viral RNA and antibodies for SARS-CoV-2 during the second wave of human infections in Mexico, and to recognize the major risk factors related to host and pet ownership behavior. We evaluated two study groups, cats and dogs from COVID-19 infected/suspected households ( $\mathrm{n}=44)$ and those admitted for veterinary care for any reason at several veterinary hospitals in Puebla City, México $(\mathrm{n}=91)$. Using RT-PCR, we identified the presence of SARS-CoV-2 RNA in swabs of four dogs (18.2\%) and zero cats in COVID-19 infected/suspected households, within this group $31.8 \%$ of dogs and $27.3 \%$ of cats tested IgG ELISA positive, and neutralizing antibodies were detected in one dog (4.5\%) and two cats $(9.1 \%)$. In the random group, $25.0 \%$ of dogs and $43.6 \%$ of cats were ELISA positive, only one cat shown neutralizing antibodies $(2.6 \%)$. We identified no significant hematological and biochemical abnormalities as risk factors, but we found dynamic changes in leukocytes, lymphocytes, albumin/globulin rate, and creatinine. Pet age $>4$ years old, other pets at home, and daily cleaning of pet dish, were each associated with an increase of SARS- CoV-2 infection $(\mathrm{p}<0.05)$. Allowing face lick, sharing bed/food with pets, and owner tested positive or suspected of COVID-19 were not significant risk factors, but time ( $>4$ hours) the owner spent out from home during the lockdown for COVID-19 (OR=0.37, $\mathrm{p}=0.009$ ), and outdoor pet food tray $(\mathrm{OR}=0.32, \mathrm{p}=0.011)$ were negative risks factors of SARS-CoV-2 infection in pets, suggesting that time the owner spends with their pet is an important risk factor.
\end{abstract}

\section{Hosted file}

Espinosa Gomez et al_Risk factors of SARS-CoV-2 in pets Mexico_TED.docx available https://authorea.com/users/460462/articles/556468-host-traits-ownership-behavior-andrisk-factors-of-sars-cov-2-infection-in-domestic-pets-in-mexico 